\title{
Multi-location Evaluation of Phytohormones and Chemicals for the Management of Pigeonpea Sterility Mosaic Disease (PSMD)
}

\author{
B. R. Sayiprathap ${ }^{1,2}$, A. K. Patibanda ${ }^{2}$, V. Prasanna Kumari², \\ K. Jayalalitha ${ }^{2}$, V. Srinivasa Rao ${ }^{2}$ and Hari Kishan Sudini ${ }^{*}$ \\ ${ }^{1}$ International Crops Research Institute for the Semi-Arid Tropics, \\ Patancheru, Telangana, India \\ ${ }^{2}$ Acharya N.G. Ranga Agricultural University, Guntur, Andhra Pradesh, India \\ *Corresponding author
}

\section{A B S T R A C T}

\begin{tabular}{|l|}
\hline Ke y w o r d s \\
Pigeonpea, Sterility \\
mosaic disease \\
(SMD), Disease \\
management
\end{tabular}

Sterility mosaic disease (SMD) is the most destructive disease of pigeonpea in the Indiansubcontinent. SMD is caused by Pigeonpea sterility mosaic virus (PPSMV) and strain variability coupled with recent discovery of another emaravirus (PPSMV-II) made a complex etiology of this difficult to manage viral disease. A field study with phytohormones, chemicals and plant extract was conducted at Bengaluru and Patancheru locations to find out the best treatment for the management of SMD in pigeonpea. Results from the two field trials suggest three sprays of proporgite @ $0.15 \%$, recorded least SMD incidence of 2.00 per cent and effectively control the disease by 93.18 per cent with 80.33 per cent yield increase over control. Similarly, dimethoate @ $0.10 \%$ also showed significant reduction of disease incidence by 92.86 per cent with 79.53 per cent yield increase. Spraying of salicylic acid (SA) @ $0.10 \mathrm{mM}$ and gibberellic acid (GA) @ 250 ppm offered resistance to SMD infection with 40.67 and 42.69 per cent yield increase respectively over the contol. However, indole acetic acid (IAA) @ 250 ppm and Mirabilis jalapa bulb extract (yellow flower) @ $5.00 \%$ sprays were not effective in the management of SMD.

\section{Introduction}

Sterility mosaic disease (SMD) of pigeonpea also referred to as "Green Plague" is first reported in 1931 from Pusa, Bihar state of India (Mitra, 1931) and subsequently from other states of India. It is considered to be the most destructive disease of pigeonpea in all growing regions causing yield losses up to 205,000 tonnes annually in India (Kannaiyan et al., 1984). The incidence of SMD varies from year to year and place to place, on susceptible cultivars, early-stage infection (<45-day-old plants) showed characteristic disease symptoms and near-complete cessation of flowering (sterility) and resulted in 95-100\% loss in yield (Kannaiyan et al., 1984; Reddy et al., 1995). The SMD is caused by an emaravirus, Pigeonpea sterility mosaic virus (PPSMV) (Elbeaino et al., 2015; Kumar 
et al., 2000) and transmitted by an eriophyid mite, Aceria cajani Channabasavanna (Acari: Arthropoda) (Seth 1962) in a semi-persistent manner (Kulakarni et al., 2002).

Plant virus diseases are managed either through the control of vectors and/or by the application of antiviral compounds. Though several insecticides/ acaricides have been reported to control the vector mite of SMD, they were considered not safe for environment. There is less exploitation of plant hormones like salicylic acid(SA)which induces systemic acquired resistance (SAR)to a wide range of microbial pathogens, including viruses (Delaney et al., 1994) by interfering with three main stages of the plant viral cycle: replication, cell-to-cell movement, and long-distance movement (Aminalah et al., 2011). Green plants are also the source of potential antiviral principles that are effective against a wide range of plant viruses. Extracts of Mirabilis jalapa, containing a ribosomeinactivating protein (RIP) Mirabilis antiviral protein (MAP), inhibited infection of viruses such as Tobacco mosaic virus (TMV), Cucumber green mottle mosaic virus, Turnip mosaic, Cucumber mosaic, Potato virus $X$, Potato virus $Y$, Potato leaf roll virus, and potato spindle tuber viroid (Kubo et al.,1990; Vivanco et al., 1999).

Recent characterization of a second
Emaravirus, Pigeonpea sterility mosaic virusII (PPSMV-II) (PPSMV referred as PPSMV-I hereafter) associated with SMD of pigeonpea (Elbeaino et al., 2015; Kumar et al., 2017; Patil et al., 2017) made complex etiology of this difficult to manage the viral disease. In this context, the present study was conducted to identify the best treatment in the management of the SMD of pigeonpea.

\section{Materials and Methods}

A field experiment was conducted simultaneously at two different locations such as Bengaluru and Patancheru in a randomized block design (RBD) with 3 replications and 7 treatments to find out the best treatment for the management of pigeonpea sterility mosaic disease (SMD) during 2018 rainy season. In both the locations SMD is a major production constraint in pigeonpea. A highly susceptible genotype, ICP-8863 was used for the study. Seven tratements such as three phytohormones, two chemicals, one plant extract and an untreated check were included in the study at both the locations. While imposing treatments, totally three sprays are given, First at 20 days after sowing followed by mite-infested virus inoculation by leaf stapling method. Second and third sprays were conducted on the $40^{\text {th }}$ and $60^{\text {th }}$ day after sowing.

Treatments imposed on pigeonpea for the management of SMD

\begin{tabular}{|c|c|c|}
\hline Treatments & Chemical & Concentration \\
\hline $\mathrm{T}_{1}$ & Salicylic acid (SA) & $0.10 \mathrm{mM}$ \\
\hline $\mathrm{T}_{2}$ & Indole acetic acid (IAA) & $250 \mathrm{ppm}$ \\
\hline $\mathrm{T}_{3}$ & Gibberllic acid (GA) & $250 \mathrm{ppm}$ \\
\hline $\mathrm{T}_{4}$ & Proporgite (Omite 57 \% EC) & $0.15 \%$ \\
\hline $\mathrm{T}_{5}$ & Dimethoate (Rogor 30\% EC) & $0.10 \%$ \\
\hline $\mathrm{T}_{6}$ & Mirabilis jalapa root extract & $5.00 \%$ \\
\hline & (yellow flower) & - \\
\hline $\mathrm{T}_{7}$ & Untreated check & - \\
\hline
\end{tabular}




\section{Leaf stapling method of virus inoculation}

Leaf stapling method was followed for virus inoculation (Nene and Reddy, 1976). It is the most efficient method for transmission of Pigeonpea sterility mosaic virus (PPSMV) onto pigeonpea. In this method, young pigeonpea leaflets from SMD plants infested with eriophyid mites, Aceria cajani are stapled onto the primary leaves of the pigeonpea in such a way that the undersurface of the disease leaflet comes in contact with both surfaces of the test plant. Mites from the diseased leaf migrate onto the test seedling and their feeding resulted in virus transmission onto the test plant.

\section{Observations and data analysis}

Observations were recorded upon complete flowering on the incidence of SMD and per cent incidence was calculated as per the following formula.

Number of SMD infected plants
$\%$ SMD incidence $=x$
Total number of plants

Per cent SMD incidence values of treatments then used to calculate PDI reduction over control using following fomula,

(Control PDI- Treatment PDI)

PDI reduction over control $=\mathrm{x}$ 100

Control PDI

The seed yield was obtained from all the treatments seaparately and the data was further analysed statistically for its significance of difference by the normal statistical procedure adopted for randomized block design and interpretation of data was carried out in accordance with Walter (1997) to know the best treatment in the effective management of sterility mosaic disease

\section{Results and Discussion}

Comprehensive analysis of data from the two field trials, conducted at Bengaluru and Patancheru locations for the management of SMD on a susceptible pigeonpea genotype ICP-8863 during rainy season 2018-19 (Figure 1) confirmed that the SMD incidence in untreated control was 97.59 per cent. Three sprays of proporgite @ $0.15 \%$, first at 20 days after sowing followed by second spray at the $40^{\text {th }}$ day and third spray at the $60^{\text {th }}$ day, recorded least SMD incidence of 2.00 per cent and effectively reduced the disease infection by 93.18 per cent with 80.33 per cent yield increase over control. Similarly, three sprays of dimethoate @ $0.10 \%$ effectively reduced the disease by 92.86 per cent with 79.53 per cent yield increase over control treatment.

Three sprays of salicylic acid (SA) @ 0.10 $\mathrm{mM}$, gibberlic acid (GA) @ $250 \mathrm{ppm}$, offers resistance to SMD infection by 6.37 and 5.88 per cent disease reduction with 40.67 and 42.69 per cent yield increase respectively over the control treatment. But, indole acetic acid (IAA) @ 250 ppm or Mirabilis jalapa bulb extract (yellow flower) @ $5.00 \%$ treatment were not effective in the management of the SMD (Table 1 and Figure2).

In the present study spraying of proporgite @ $0.15 \%$ and dimethoate @ $0.10 \%$ were showed promising results in the management of pigeonpea SMD and this results were in line with the previous findings of Manjunatha et al (2012), Maurya et al (2017) and Sudharani et al (2017) who reported proporgite $(0.15 \%)$ effectively controls SMD. Rajeswari et al (2016) reported the salicylic acid (SA)@200 ppm treatment showed effective management of SMD, however in the present study SA treatment @ $0.10 \mathrm{mM}$ was not showed significant reduction of SMD incidence. 
Table.1 Management of sterility mosaic disease (SMD) of pigeonpea during 2018 rainy season

\begin{tabular}{|c|c|c|c|c|c|c|c|c|c|}
\hline \multicolumn{2}{|c|}{ Treatments } & \multirow{2}{*}{$\begin{array}{c}\text { PDI at } \\
\text { Bengaluru }^{+} \\
\\
91.50 \\
(73.02)\end{array}$} & \multirow{2}{*}{$\begin{array}{c}\text { PDI at } \\
\text { ICRISAT }^{+} \\
\\
91.17 \\
(72.69)\end{array}$} & \multirow{2}{*}{\begin{tabular}{|c|} 
Avg. \\
PDI \\
\\
91.34 \\
$(72.85)$
\end{tabular}} & \multirow{2}{*}{$\begin{array}{c}\begin{array}{c}\text { PDI } \\
\text { reduction } \\
\text { over } \\
\text { control }\end{array} \\
6.40\end{array}$} & \multirow{2}{*}{$\begin{array}{c}\begin{array}{c}\text { Yield at } \\
\text { Bengaluru } \\
\left(\mathrm{Kg} \mathrm{ha}^{-1}\right)^{+}\end{array} \\
380.30^{\mathrm{a}}\end{array}$} & \multirow{2}{*}{$\begin{array}{c}\begin{array}{c}\text { Yield at } \\
\text { Patancheru } \\
\left(\mathrm{Kg} \mathrm{ha}^{-1}\right)^{+}\end{array} \\
457.64^{\mathrm{b}}\end{array}$} & \multirow{2}{*}{$\begin{array}{c}\begin{array}{c}\text { Avg. Yield } \\
\left(\text { Kg ha }^{-1}\right)\end{array} \\
418.97^{\text {b }}\end{array}$} & \multirow{2}{*}{\begin{tabular}{|c|}
$\begin{array}{c}\text { Per cent yield } \\
\text { increase over } \\
\text { control }\end{array}$ \\
$\mathbf{4 0 . 6 7}$
\end{tabular}} \\
\hline $\mathrm{T}_{1}$ & $\begin{array}{l}\text { Salicylic acid (SA) } \\
\text { @ } 0.10 \mathrm{mM}\end{array}$ & & & & & & & & \\
\hline $\mathrm{T}_{2}$ & $\begin{array}{l}\text { Indole acetic acid } \\
\text { (IAA) @ } 250 \mathrm{ppm}\end{array}$ & $\begin{array}{c}93.57 \\
(75.28)\end{array}$ & $\begin{array}{c}92.00 \\
(73.54)\end{array}$ & $\begin{array}{c}92.79 \\
(74.39)\end{array}$ & 4.91 & $360.80^{\mathrm{a}}$ & $295.83^{\mathrm{a}}$ & $328.32^{\mathrm{a}}$ & 24.29 \\
\hline $\mathrm{T}_{3}$ & $\begin{array}{l}\text { Gibberlic acid (GA) } \\
\text { @ } 250 \mathrm{ppm}\end{array}$ & $\begin{array}{c}91.90 \\
(73.44)\end{array}$ & $\begin{array}{c}91.33 \\
(72.85)\end{array}$ & $\begin{array}{c}91.62 \\
(73.14)\end{array}$ & 6.11 & $415.80^{\mathrm{a}}$ & $451.68^{b}$ & $433.74^{b}$ & 42.69 \\
\hline $\mathrm{T}_{4}$ & $\begin{array}{l}\text { Proporgite (Omite } 57 \\
\% \text { EC) @ } 0.15 \%\end{array}$ & $\begin{array}{c}2.33 \\
(8.78)\end{array}$ & $\begin{array}{c}1.67 \\
(7.42)\end{array}$ & $\begin{array}{c}2.00 \\
(8.13)\end{array}$ & 97.95 & $1308.33^{b}$ & $1219.49^{c}$ & $1263.91^{\mathrm{c}}$ & 80.33 \\
\hline $\mathrm{T}_{5}$ & $\begin{array}{l}\text { Dimethoate (Rogor } \\
30 \% \text { EC) @ } 0.10 \%\end{array}$ & $\begin{array}{c}2.67 \\
(9.40)\end{array}$ & $\begin{array}{c}2.00 \\
(8.13)\end{array}$ & $\begin{array}{c}2.34 \\
(8.79)\end{array}$ & 97.60 & $1257.59^{b}$ & $1171.88^{c}$ & $1214.74^{c}$ & 79.53 \\
\hline $\mathrm{T}_{6}$ & $\begin{array}{l}\text { Mirabilis jalapa root } \\
\text { extract (yellow } \\
\text { flower)@ } 5.00 \%\end{array}$ & $\begin{array}{c}95.20 \\
(77.31)\end{array}$ & $\begin{array}{c}94.13 \\
(75.95)\end{array}$ & $\begin{array}{c}94.67 \\
(76.62)\end{array}$ & 2.99 & $376.93^{\mathrm{a}}$ & $272.36^{\mathrm{a}}$ & $324.65^{\mathrm{a}}$ & 23.43 \\
\hline \multirow[t]{3}{*}{$\mathrm{T}_{7}$} & Untreated check & $\begin{array}{c}97.80 \\
(81.44)\end{array}$ & $\begin{array}{c}97.37 \\
(80.64)\end{array}$ & $\begin{array}{c}97.59 \\
(81.03)\end{array}$ & - & $277.56^{\mathrm{a}}$ & $219.55^{\mathrm{a}}$ & $248.56^{\mathrm{a}}$ & - \\
\hline & C.D. $(p \leq 0.05)$ & 5.85 & 5.47 & 5.66 & & 160.89 & 101.77 & 131.33 & \\
\hline & C.V. & 5.87 & 5.40 & 5.63 & & 14.45 & 9.87 & 12.16 & \\
\hline
\end{tabular}

${ }^{+}$Avg. of three replications

values in the paranthesis are arcsin transformed 
Fig.1 Typical symptoms of sterility mosaic disease (SMD), yellow mosaic (a), chlorotic ring spots (b), a field experiment of pigeonpea crop for evaluation of chemicals for management of SMD (c), leaf stapling method of virus inoculation on to pigeonpea seedling (inside picture)

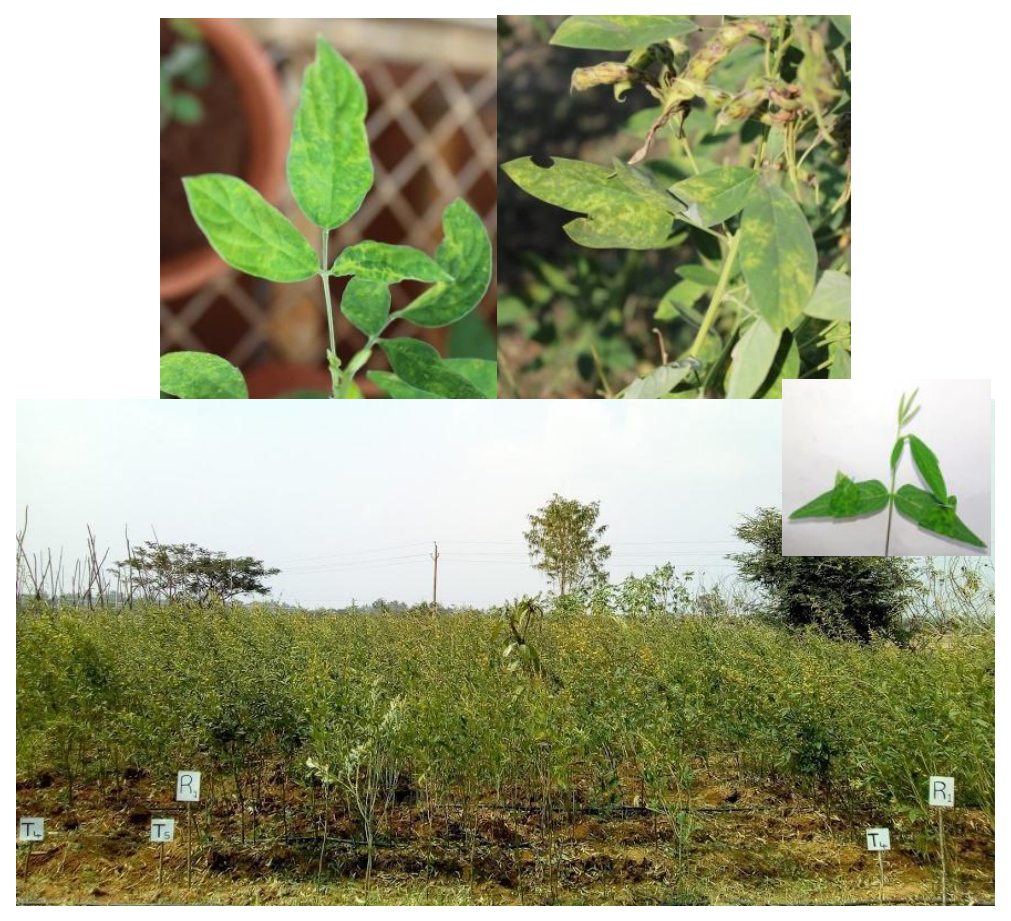

Fig.2 Frequency distribution of per cent SMD reduction and yield increase in treatments over the control upon treatment imposition

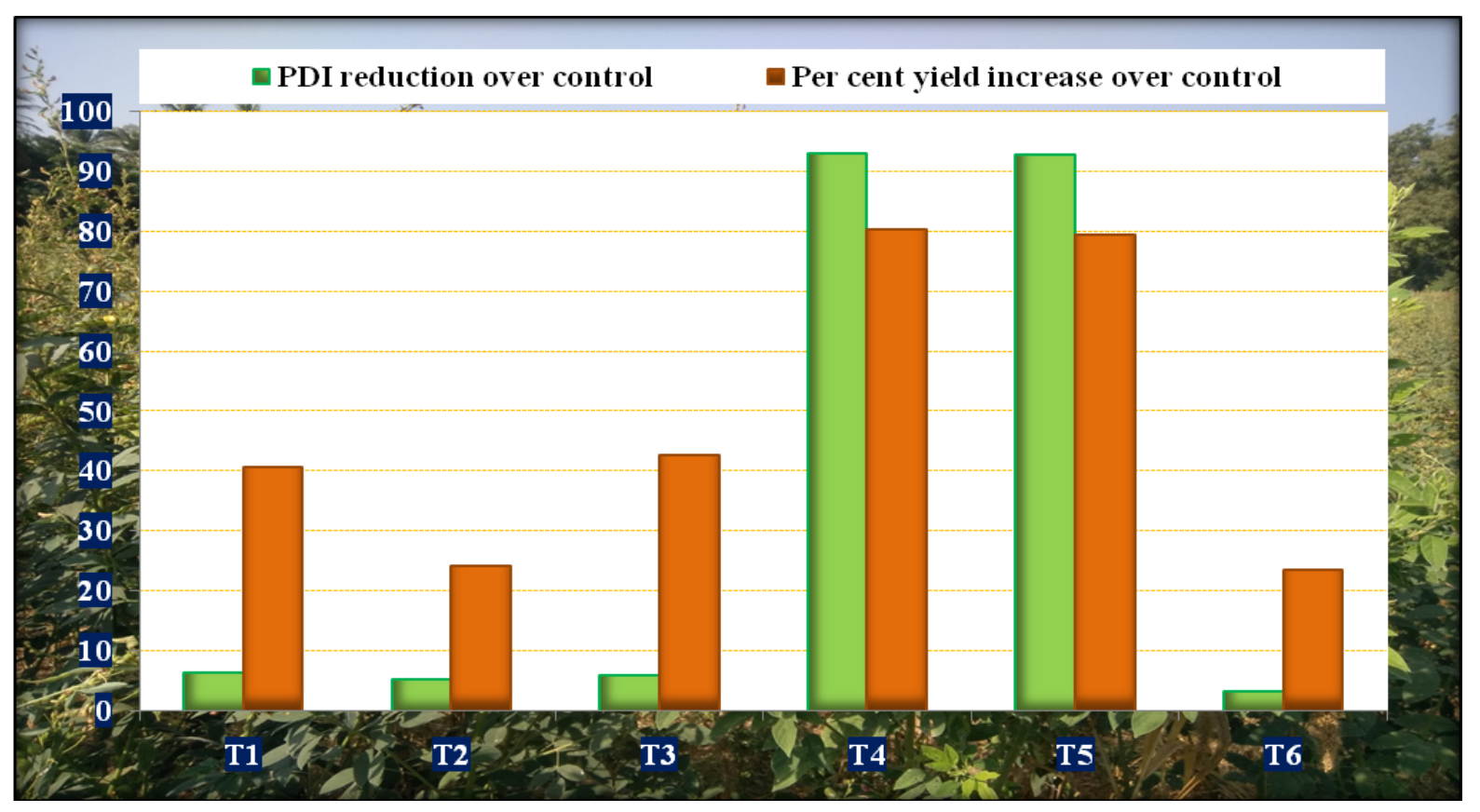


Insecticidesare always the first choice of the farmers for the management of any crop pests/ vectors of plant diseases, because of their quick knockdown effect. Several insecticides/ acaricides such as dicofol (0.25 $\%$ ), fenazaquin $(0.25 \%)$, wettable sulphur $(0.3 \%)$, difenthurion $(0.1 \%)$, spiromesifen $(0.1 \%)$, dicofol $(0.2 \%)$, abemectin $(0.05 \%)$, mitex $(0.05 \%)$, have been found effective in controlling the vector mite (Aceria cajani) of the SMD (De et al., 1995; Kanadulna et al., 2004; Manjunatha et al., 2017; Maurya et al., 2017; Rajeswari et al., 2016; Sudharani et al., 2017). Phytoharmones such as salicylic acid and jasmonic acid, and plant extracts (Mirabilis jalapa bulb extract, azadirachtin, neem oil, wintergreen oil, Vitex negundo leaf extract, Psoralea corylifola leaf extract) also have been reported to having the positive effect on controlling the plant virus and their vectors (Maurya et al., 2017; Ong and Cruz, 2016; Rajeswari et al., 2016; Sudharani et al., 2017).In the present invistagation salicylic acid@0.10 mMand gibberlic acid @250 ppm treatment offered reasonably good levels of control. So, SA and GA could be included alternative to chemical sprays to reduce the development of resistance by the virus and/or vector to a particular group of chemical. Though chemical management is effective but is not economical so, there is a need for exploitation of economical and environmentally friendly management strategies for any plant disease.

\section{Acknowledgement}

First author thankfull to University Grants Commission (UGC) for financial support.

\section{References}

Aminalah, T., Z. Maryam, T. Asma, D. Akbar and Mina, K.H. 2011. Role of salicylic acid in resistance to plant viruses.
Genetics in the $3^{\text {rd }}$ Millennium. 8: 22032212.

De, R.K., V. Dhar, and Rathore, Y.S. 1996. Control of mosaic in pigeonpea with insecticides and acaricides. Indian Journal of Pulses Research. 11: 47-48.

Delaney, T.P., S. Uknes, B. Vernooij, L. Freidrich, K. Weyman, D. Negrotto, T. Gaffney, M. Gut-Rella, H. Kessmann, E. Ward and Ryals, J. 1994. A central role of salicylic acid in plant disease resistance. Science. 266: 1247-1 250.

Elbeaino, T., M. Digiaro, M. Uppala and Sudini, H. 2015. Deep sequencing of dsRNAs recovered from mosaicdiseased pigeonpea reveals the presence of a novel emaravirus, Pigeonpea sterility mosaic virus 2. Archives of Virology. 160: 2019-2029.

Kanadulna, A., J. Singh and Prasad, R. 2004. Acaricidal efficacy of some newer insecticides against Aceria cajani. In: Environment and Management (Eds.). A. Kumar, APH Publisher. New Delhi. 115-118.

Kannaiyan, J., Y. L. Nene, M. V. Reddy, J. G. Ryan and Raju, T.N. 1984. Prevalence of pigeonpea diseases and associated crop losses in Asia, Africa and the Americas. Tropical Pest Management. 30(1): 62-71.

Kubo, S., T. Ikeda, S. Imaizumi, Y. Takanami and Mikami, Y. 1990. A potent plant virus inhibitor found in Mirabilis jalapa (L.). Annals of the Phytopathological Society of Japan. 56: 481-487.

Kulkarni, N.K., P. L. Kumar, V. Muniyappa, A. T. Jones and Reddy, D.V.R. 2002. Transmission of Pigeonpea sterility mosaic virus by the eriophyid mite, Aceria cajani (Acari: Arthropoda). Plant Disease. 86: 1297-1302.

Kumar, P.L., A. T. Jones, P. Sreenivasulu and Reddy, D.V.R. 2000. Breakthrough in the identification of the causal virus of pigeonpea sterility mosaic disease. 
Journal of Mycology and Plant Pathology. 30(2): 249.

Kumar, S., B. L. Subbarao and Vipin, H. 2017. Molecular characterization of emaraviruses associated with pigeonpea sterility mosaic disease. Nature: Scientific reports. 7: 11831.

Manjunatha, L., H. K. Ramappa, S. R. V. Mahantesha, M. B. Gowda, P. V. Rajappa and Kavitha T.R. 2012. Management of sterility mosaic disease (SMD) of pigeonpea. Plant Archives. 12(2): 1007-1012.

Maurya, R. K., B. Kumar,R. Kumar and Singh, M. 2017. Transmission of Pigeonpea sterility mosaic virus and management of sterility mosaic disease of pigeonpea by different acaricides under middle IGP of Bihar. International Journal of Current Microbiology and Applied Sciences. 6(8): 3711-3716.

Mitra, M. 1931. Report of the Imperial Mycologist. Sci. Rep. Agric. Res. Inst. Pusa 19:58-71. 36. Mosaic of pigeonpea. In: Plant Diseases of International Importance: Diseases of Cereals and Pulses (Eds.). U. S. Singh, A. N. Mukhopadhyay, J. Kumar and H. S. Chaube. Prentice Hall, Englewood Cliffs, NJ.

Nene, Y.L., and Reddy, M.V. 1976. A new technique to screen pigeonpea for resistance to sterility mosaic. Tropical Grain Legume Bulletin. 5: 23-24.

Ong. S and Cruz, F.C.S. 2016. Effect of exogenous application of salicylic acid on the severity of tomato leaf curl disease. 22 (1): 137-145.

Patil, B.P., D. Meenakshi and Ritesh, M. 2017. Variability of emaravirus species associated with sterility mosaic disease of pigeonpea in India provides evidence of segment reassortment. Viruses. 9: 183

Rajeswari, E., K. P. Smitha, A. Kamalakannan, D. Alice and Kannan Bapu, J.R. 2016. Management of pigeonpea sterility mosaic disease. Legume Research. 39(4): 648-650

Reddy, M.V., V. K. Sheila, A. K. Murthy and Padma, P. 1995. Mechanism of resistance to Aceria cajani in pigeonpea. International Journal of Tropical Plant Diseases. 13: 51-57.

Seth, M.L. 1962. Transmission of pigeonpea sterility by an eriophyid mite. Indian Phytopathology. 15: 225-227.

Sudharani, Y. S. Amaresh, M. K. Naik, H. Arunkumar and Sunkad, G. 2017. Management of sterility mosaic disease through vector management. Indian Journal of Agricultural Research. 51(5): 498-501.

Vivanco, J.M., M. Querci and Salazar, L.F. 1999. Antiviral and antiviroid activity of MAP-containing extracts from Mirabilis jalapa roots. Plant Disease. 83: 11161121.

Walter, P.F. 1997. Experimental design theory and applications. $3^{\text {rd }}$ edition, Newyork.

\section{How to cite this article:}

Sayiprathap, B. R., A. K. Patibanda, V. Prasanna Kumari, K. Jayalalitha, V. Srinivasa Rao and Hari Kishan Sudini. 2020. Multi-location Evaluation of Phytohormones and Chemicals for the Management of Pigeonpea Sterility Mosaic Disease (PSMD). Int.J.Curr.Microbiol.App.Sci. 9(07): 3278-3284. doi: https://doi.org/10.20546/ijcmas.2020.907.381 